\title{
Organic Matter Fractions and Carbon Management Index in Oxisol Under Integrated Agricultural Production Systems
}

Carlos Augusto Rocha de Moraes Rego

Center of Agrarian Sciences, Western Paraná State University (UNIOESTE), Street Pernambuco, 1777 - Center, Zip Code: 85960-000, Marechal Cândido Rondon - PR, Brazil

Tel: +55 $9898747-1864$

E-mail: cassielcarlos@ hotmail.com

Paulo Sérgio Rabello de Oliveira

Center of Agrarian Sciences, Western Paraná State University (UNIOESTE),

Street Pernambuco, 1777 - Center, Zip Code: 85960-000, Marechal Cândido Rondon - PR, Brazil

E-mail: rabello.oliveira@ @otmail.com

\section{Jeferson Tiago Piano}

Center of Agrarian Sciences, Western Paraná State University (UNIOESTE),

Street Pernambuco, 1777 - Center, Zip Code: 85960-000, Marechal Cândido Rondon - PR, Brazil

E-mail: jefersontpiano@hotmail.com

Jean Sérgio Rosset

University Unit of Mundo Novo, State University of Mato Grosso do Sul (UEMS)

BR 163 km 20.2, BR-163, Km 20.2, Zip Code: 79980-000, Mundo Novo - MS, Brazil.

E-mail: jsrosset@hotmail.com 
Jonas Francisco Egewarth

Center of Agrarian Sciences, Western Paraná State University (UNIOESTE),

Street Pernambuco, 1777 - Center, Zip Code: 85960-000, Marechal Cândido Rondon - PR, Brazil

E-mail: jonas.egewarth@gmail.com

Eloisa Mattei

Center of Agrarian Sciences, Western Paraná State University (UNIOESTE),

Street Pernambuco, 1777 - Center, Zip Code: 85960-000, Marechal Cândido Rondon - PR, Brazil

E-mail: eloisa-mattei@hotmail.com

\title{
Marinez Carpiski Sampaio
}

Center of Agrarian Sciences, Western Paraná State University (UNIOESTE),

Street Pernambuco, 1777 - Center, Zip Code: 85960-000, Marechal Cândido Rondon - PR, Brazil

E-mail: mari_marinez@hotmail.com

Juan López de Herrera

Higher Technical School of Agricultural Engineers, Technical University of Madrid (UPM)

Avenue Puerta de Hierro, 2, Zip Code: 28040, Madrid, Spain.

E-mail: jnlopezh@gmail.com

Received: Feb. 1, 2020

doi:10.5296/jas.v8i3.16325
Accepted: Mar. 2, 2020 Published: Mar. 3, 2020

URL: https://doi.org/10.5296/jas.v8i3.16325

\begin{abstract}
This work aimed to evaluate the oxidizable and chemical fractions of organic matter and the carbon management index in different integrated agricultural production systems, hay production and native forest areas in an Oxisol. Nine areas with different management systems were evaluated being six managements of the combination between different oat
\end{abstract}


density (40 and $60 \mathrm{~kg} \mathrm{ha}^{-1}$ ) and grazing frequencies (0, 1 and 2) in autumn-winter and soybean succession in spring-summer, one with natural reseeding ryegrass and forage turnip in autumn-winter and soybean succession in spring-summer and two reference areas. In each soil management systems were collected soil samples composite in the 0-5, 5-10 and 10-20 $\mathrm{cm}$ layers and determined the Total Organic Carbon (TOC), humic substances (Fulvic Acids FA, Humic Acids - HA and humin - HUM), the carbon in the oxidizable fractions (F1, F2, F3 and F4) and Carbon Management Index (CMI). Were observed that chemical, oxidizable fractions and CMI, do not have significant differences between with the various managements each other. For TOC, HA, HUM, F1, F3, F4 and CMI, the managements did not differ from the reference areas indicating maintenance of soil carbon.

Keywords: degree of oxidation of organic carbon, integrated crop-livestock system, humic substances, soil management, total organic carbon

\section{Introduction}

The conversion of natural vegetation to the implantation of agricultural activities causes an imbalance in the ecosystem, since the adopted management will influence the physical, chemical and biological processes of the soil. In this way, the understanding of the performance of different soil management systems allows us to subsidize strategies for the maintenance of its long-term effects, in order to guarantee the sustainability and the quality of natural resources (Rossi et al., 2012; Rosset et al., 2016).

The sustainability of any agricultural production system is due to the need to maintain a productive and balanced soil, especially in relation to the improvement of soil attributes and preservation of soil organic matter (SOM). In an attempt to balance the agricultural productivity with the conservation of the environment, farming concepts were developed based on nutrient cycling, soil conservation and crop diversification (Silva et al., 2011).

The development of management strategies based on conservation of soil environment, such as integrated agricultural production systems (IAPS), are aimed at the sustainable intensification. This is based on the spatial and temporal integration of productive components, whose purpose is to achieve higher stages of environmental quality and competitiveness, reducing the pressure on the opening of new areas and contributing to soil improvement (Cordeiro et al., 2015).

One of the ways of assessing soil quality is by quantifying the organic carbon content related to humic (SH) and oxidizable substances from SOM (Ebeling et al., 2011; Rosset et al., 2016), serving as indicators of the fractionated carbon content and sustainability performance management. They are considerable indicators of the processes and the degree of humification of the SOM, presenting around 70 to $90 \%$ of the total organic carbon (TOC) of the soil being divided into 3 fractions: humic acids (HA), fulvic acids (FA) and humin (HUM) (Primo et al., 2011; Rosset et al., 2016; Mendonça \& Matos, 2017).

Oxidizable fractions, quantified by different degrees of oxidation of the SOM, are used as indicators of the impacts caused by the management about the content and deposition of SOM (Rangel et al., 2008). According to Chan et al. (2001), there are four fractions: F1, F2, 
F3 and F4. Fractions F1 and F2 are associated with the formation of macroaggregates and nutrient availability, being the F1 fraction the greater lability in the soil (Guareschi et al., 2013; Rosset et al., 2016) and the F3 and F4 fractions are related to greater chemical stability compounds, resulting from the decomposition and humification of SOM, being the F4 of greater resistance to degradation and consequent longer time permanence in soil (Rangel et al., 2008; Guareschi et al., 2013).

Due to the fact that SOM is the largest deposit of carbon on the land surface, the need for indexes that can assess the ability of the different management systems to maintain or increase soil carbon content are extremely necessary (Primo et al., 2011). Therefore, Blair et al. (1995) presented the carbon management index (CMI). Then, Rangel et al. (2008) proposed some modifications in relation to the determination of this index, as a relative measure of the changes caused by the management when they are compared to a situation considered original/reference, taking into account the lability of SOM and seeking to unite the quantitative and qualitative characteristics of SOM, as a way to evaluate the performance of a given management system (Rossi et al., 2012).

In view of the above, this work aims to evaluate the oxidizable and chemical fractions of organic matter and the carbon management index in different integrated agricultural production systems, hay production and native forest areas in an Oxisol.

\section{Material and Methods}

\subsection{Location, Climate and Soil of the Study Area}

The work was carried out at the Experimental Farm "Professor Antônio Carlos dos Santos Pessoa", belonging to the Western Paraná State University (UNIOESTE), located in the municipality of Marechal Cândido Rondon, state of Paraná, under WGS84 coordinates $24^{\circ} 31^{\prime} 58.24^{\prime \prime} \mathrm{S}$ and $54^{\circ} 01^{\prime} 12.08^{\prime \prime} \mathrm{W}$ with an altitude of 390 meters. According to the classification of Köppen, the climate of the region is of type Cfa, subtropical humid of dry winter, with rainfall well distributed throughout the year and hot summers with an annual mean temperature between 22 to $23^{\circ} \mathrm{C}$ and an average annual rainfall of 1600 to 1800 millimeters (Alvares et al., 2014). The soil of the experimental area is classified as a Oxisol with a very clayey texture, presenting in the layer of 0.00 to $0.10 \mathrm{~m}$ values of $681.0 \mathrm{~g} \mathrm{~kg}^{-1}$ of clay, $266.5 \mathrm{~g} \mathrm{~kg}^{-1}$ of silt and $52.5 \mathrm{~g} \mathrm{~kg}^{-1}$ of sand. For the layer $0.10-0.20 \mathrm{~m}$ values $751.5 \mathrm{~g} \mathrm{~kg}^{-1}$ of clay, $199.1 \mathrm{~g} \mathrm{~kg}^{-1}$ of silt and $49.4 \mathrm{~g} \mathrm{~kg}^{-1}$ of sand.

\subsection{Characterization of the Experimental Area}

Nine distinct areas were evaluated, consisting of six areas that were cultivated in the autumn-winter with different densities of oats sowing (40 kg ha ${ }^{-1}$ and $60 \mathrm{~kg} \mathrm{ha}^{-1}$ ) and grazing frequencies $(0,1$ and 2$)$ with soybean succession in spring-summer, one area in the autumn-winter period occurred natural reseeding ryegrass and forage turnip (RNAN) and soybean succession in spring-summer and two management systems as reference areas, being a of hay production with Tifton 85 grass (Haying) and a native forest (Forest) (Table 1). 
Table 1. Description of the areas under study

Areas Description

No-till system

Cultivated in autumn-winter with oats (Avena sativa L.) in seeding density of $40 \mathrm{~kg} \mathrm{ha}^{-1}$ during the 2014/2015, 2015/2016 and 2016/2017 agricultural years, using $250 \mathrm{~kg} \mathrm{ha}^{-1}$ of commercial formulation $10-15-15\left(\mathrm{~N}, \mathrm{P}_{2} \mathrm{O}_{5}\right.$ and $\mathrm{K}_{2} \mathrm{O}$ ) in the basic fertilization and $120 \mathrm{~kg} \mathrm{ha}^{-1}$ of nitrogen in the form of (O40) urea in covered, applied in two parts, at the beginning of tillering and 30 days after the first application. During spring-summer periods, soybean was cultivated with base fertilization of 270 (2014/2015), 290 (2015/2016) and $310(2016 / 2017) \mathrm{kg} \mathrm{ha}^{-1}$ of commercial formulation 02-20-18 (N, $\mathrm{P}_{2} \mathrm{O}_{5}$ and $\mathrm{K}_{2} \mathrm{O}$ ) and phytosanitary treatments carried out according to the need of the crop.

Integrated Crops and managements during autumn-winter and spring-summer equal to agricultural A40 area. The difference was that once grazing was performed on oat plants production systems (O40G1) when they were between 0.25 and $0.35 \mathrm{~m}$ high and the removal of the animals occurred when they presented rest height from 0.15 to $0.2 \mathrm{~m}$.

Integrated

Crops and managements during autumn-winter and spring-summer equal to agricultural A40 area. The difference was that twice grazing was performed on oat production plants when they were between 0.25 and $0.35 \mathrm{~m}$ high and the removal of the systems animals occurred when they presented rest height from 0.15 to $0.2 \mathrm{~m}$.

(O40G2)

No-till system (O60)

Integrated agricultural production systems (O60G1)

Integrated agricultural production systems (O60G2)
Crops and managements during autumn-winter and spring-summer equal to A40 area. The differences were in the oat seeding density that was $60 \mathrm{~kg}$ $\mathrm{ha}^{-1}$.

Crops and managements during autumn-winter and spring-summer equal to A60 area. The difference was that once grazing was performed on oat plants when they were between 0.25 and $0.35 \mathrm{~m}$ high and the removal of the animals occurred when they presented rest height from 0.15 to $0.2 \mathrm{~m}$.

Crops and managements during autumn-winter and spring-summer equal to A60 area. The difference was that twice grazing was performed on oat plants when they were between 0.25 and $0.35 \mathrm{~m}$ high and the removal of the animals occurred when they presented rest height from 0.15 to $0.2 \mathrm{~m}$. 
Natural reseeding (RNAN)

Hay Production (Haying)

Secondary Forest (Forest)
Intended to fallow during autumn and winter, but because the soil seed bank was natural reseeding of ryegrass and forage turnip species, not being performed phytotechnical managements. During spring-summer periods, soybean was cultivated with base fertilization of 270 (2014/2015), 290 (2015/2016) and $310(2016 / 2017) \mathrm{kg} \mathrm{ha}^{-1}$ of commercial formulation 02-20-18 $\left(\mathrm{N}, \mathrm{P}_{2} \mathrm{O}_{5}\right.$ and $\left.\mathrm{K}_{2} \mathrm{O}\right)$ and phytosanitary treatments carried out according to the need of the crop.

Production of hay with Tifton 85 grass (Cynodon spp.) over the last 10 years and with periodic fertilization of pig liquid manure. Are performed annually six cuts and deposition of $70.72 \mathrm{~m}^{3} \mathrm{ha}^{-1}$ of liquid manure of pigs for cutting with maintenance fertilizer.

Fragment of native forest, classified as Semideciduous Seasonal Forest, kept under permanent preservation with the presence of the species: Anadenanthera colubrina(Vell.) Brenan var. cebil (Griseb.) Altschul, Peltophorum dubium (Spreng.) Taub, Uncaria ssp., Handroanthus ssp., Aspidosperma polyneuron Müll.Arg, Caesalpinia leiostachya (Benth.) Ducke, Ceiba speciosa (St.-Hill.) Ravenna, Euterpe edulis Mart., and other local shrubs and species.

\subsection{Field Sampling and Performed Analysis}

Soil samples were collected in March 2017, at the end of the soybean cycle and almost one year after forage sowing. In each area plots of $50 \mathrm{~m}^{2}$ were defined and five single samples collected with the aid of an auger Dutch type, which were homogenized to form a composed samples on layers of 0.00 to $0.05,0.05-0.10$, and $0.10-0.20 \mathrm{~m}$. All analysis were performed based on the composite samples collected and were determined the chemical soil attributes, total organic carbon content and granulometric physical fractions of the soil.

We determine the Total Organic Carbon (TOC) by wet oxidation using potassium dichromate solution $0.167 \mathrm{~mol} \mathrm{l}^{-1}$ and concentrated sulfuric acid with heating in a digester block, according to Mendonça and Matos (2017).

To carry out the fractionation of humic substances (HS), or chemical, the method based on differential solubility and subsequent determination of carbon each fraction was used, these being: humin (HUM), fulvic acid (FA) and humic acid (HA), established by the International Society of Humic Substances and adapted by Mendonça \& Matos (2017). After determination of the carbon content in HS the following ratios were calculated: HA/FA (indicates the mobility of the carbon in the soil and the degree of humification) and carbon alkaline extract (AE)/HUM (indicates illuvial of organic matter in soil profile) for verifying the humidification processes of the SOM and humification index (HI), proposed by Canellas \& Santos (2005), calculated by the formula HI = [(FA+HA+HUM $) / T O C] \times 100$.

The oxidizable fractionation was obtained by degrees of oxidation, as established by Chan et 
al. (2001) and adapted by Mendonça \& Matos (2017), which are obtained four fractions with decreasing degrees of lability F1, F2, F3 and F4 subsequently determining the carbon in the F1 fraction was considered as labile carbon (LC) and the non-labile carbon (NLC) obtained by difference: TOC=NLC-LC. Subsequently order to obtain indexes to facilitate understanding of the dynamics of the fractions obtained, the following ratio were performed: $\mathrm{F} 1 / \mathrm{F} 4,(\mathrm{~F} 1+\mathrm{F} 2) /(\mathrm{F} 3+\mathrm{F} 4)$ and $\mathrm{LC} / \mathrm{TOC}$.

For carbon management index (CMI) was considered the proposed Rangel et al. (2018), adapted from Blair et al. (1995), using the carbon content in the fraction F1 as labile carbon (LC) and the non-labile carbon (NLC) with the basis for the calculation of the indexes that precede the determination of CMI. The proposed Rangel et al. (2018) for CMI was obtained from the following indices: Carbon compartment index $(\mathrm{CCI})=$ management of the TOC/reference of the COT; lability (L)=LC/NLC; lability index (IL)=management of the $\mathrm{L} /$ reference of the L; and subsequently determining the CMI by the formulas CCIxILx100. Because it is a study that used two areas as reference areas (Forest and Haying) for the calculation of CMI, the native forest area was used as reference $(\mathrm{CMI}=100)$, since it deals with the environment without anthropic interference.

\subsection{Statistical Analysis}

The experimental design was a completely randomized design, considering nine treatments (managements systems) with four sample units randomly collected within each area (Ferreira et al., 2012), totaling 36 plots experiments. The data were submitted to analysis of variance (ANOVA) and when significant by the F test $(\mathrm{p} \leq 0.05)$ the means of the managements by the reference areaswere compared by Dunnett's test and between managements by Tukey test, with software Genes (Cruz, 2013).

\section{Results and Discussion}

\subsection{Total Organic Carbon and Chemical Fractions}

The managements that presented the same letter "A" differ by the Tukey test $(\mathrm{p} \leq 0.05)$ from those that did not present this letter (Table 2). Differences were observed for TOC, 0.10-0.20 $\mathrm{m}, \mathrm{FA}, 0.00-0.05 \mathrm{~m}, \mathrm{HA} / \mathrm{FA}, 0.00-0.05 \mathrm{~m}$, and HI, 0.05-0.10 m, in which the managements O60G1, O40, A60 and O60G2 respectively, presented the highest values when compared to the others (Table 2).

Table 2. Total organic carbon (TOC) and the chemical fractions of soil organic matter, ratio between chemical fractions (HA/FA and AE/HUM), alkaline extract (AE) and humification index (HI) in different soil managements systems

\begin{tabular}{|c|c|c|c|c|c|c|c|c|}
\hline \multirow{2}{*}{ Areas } & TOC & FA & HA & HUM & \multirow{2}{*}{ HA/FA } & $\mathbf{A E}$ & \multirow{2}{*}{ AE/HUM } & HI \\
\hline & ------. & -.- & & ------- & & $\mathrm{g} \mathrm{kg}^{-1}$ & & $\%$ \\
\hline
\end{tabular}

\begin{tabular}{|c|c|c|c|c|c|c|c|c|}
\hline \multicolumn{9}{|c|}{$0.00-0.05 \mathrm{~m}$} \\
\hline $\mathrm{O} 40$ & $27.32 \mathrm{ab}$ & $3.31 \mathrm{bA}$ & $3.58 \mathrm{ab}$ & $14.08 \mathrm{~b}$ & $1.09 \mathrm{abAB}$ & $6.89 \mathrm{~b}$ & $0.49 \mathrm{ab}$ & $77.32 \mathrm{ab}$ \\
\hline
\end{tabular}




\begin{tabular}{|c|c|c|c|c|c|c|c|c|}
\hline O40G1 & $25.01 \mathrm{~b}$ & $3.22 \mathrm{bAB}$ & $3.32 \mathrm{~b}$ & $13.51 \mathrm{~b}$ & $1.03 \mathrm{abB}$ & $6.54 \mathrm{~b}$ & $0.49 \mathrm{ab}$ & $80.15 \mathrm{ab}$ \\
\hline O40G2 & $24.31 \mathrm{~b}$ & $2.93 \mathrm{bAB}$ & $3.63 \mathrm{ab}$ & $13.75 \mathrm{~b}$ & $1.23 \mathrm{abAB}$ & $6.56 \mathrm{~b}$ & $0.49 \mathrm{ab}$ & $83.97 \mathrm{ab}$ \\
\hline O60 & $25.40 \mathrm{~b}$ & $2.62 \mathrm{bB}$ & $3.66 \mathrm{ab}$ & $15.85 \mathrm{ab}$ & $1.40 \mathrm{~A}$ & $6.28 \mathrm{~b}$ & $0.41 \mathrm{ab}$ & $87.57 \mathrm{ab}$ \\
\hline O60G1 & $27.21 \mathrm{ab}$ & $3.05 \mathrm{bAB}$ & $3.50 \mathrm{ab}$ & $16.56 \mathrm{ab}$ & $1.16 \mathrm{abAB}$ & $6.55 \mathrm{~b}$ & $0.40 \mathrm{ab}$ & $84.89 a b$ \\
\hline O60G2 & $24.73 b$ & $3.01 \mathrm{bAB}$ & $3.71 \mathrm{ab}$ & $13.71 \mathrm{~b}$ & $1.24 \mathrm{abAB}$ & $6.72 \mathrm{~b}$ & $0.50 \mathrm{ab}$ & $82.41 \mathrm{ab}$ \\
\hline RNAN & $23.52 \mathrm{~b}$ & $3.10 \mathrm{bAB}$ & $3.24 \mathrm{~b}$ & $14.16 \mathrm{~b}$ & $1.05 \mathrm{abAB}$ & $6.33 b$ & $0.45 \mathrm{ab}$ & $87.27 \mathrm{ab}$ \\
\hline Forest & $31.73 \mathrm{a}$ & $4.57 \mathrm{a}$ & $4.40 \mathrm{a}$ & $19.13 \mathrm{a}$ & $0.96 \mathrm{a}$ & $8.97 \mathrm{a}$ & $0.47 \mathrm{a}$ & 88.58 a \\
\hline Haying & $25.49 \mathrm{~b}$ & $3.15 \mathrm{~b}$ & $3.19 \mathrm{~b}$ & $16.21 \mathrm{~b}$ & $1.01 \mathrm{~b}$ & $6.34 \mathrm{~b}$ & $0.39 \mathrm{~b}$ & $88.45 b$ \\
\hline \multicolumn{9}{|c|}{$0.05-0.10 \mathrm{~m}$} \\
\hline $\mathrm{O} 40$ & $22.11 b$ & $2.82 \mathrm{~b}$ & $3.12 \mathrm{~b}$ & $13.01 \mathrm{~b}$ & $1.12 \mathrm{ab}$ & $5.93 \mathrm{~b}$ & $0.46 \mathrm{ab}$ & $86.26 \mathrm{abAB}$ \\
\hline O40G1 & $21.57 \mathrm{~b}$ & $2.73 \mathrm{~b}$ & $3.08 \mathrm{~b}$ & $12.79 \mathrm{~b}$ & $1.13 \mathrm{ab}$ & $5.82 \mathrm{~b}$ & $0.46 \mathrm{ab}$ & $86.52 \mathrm{abAB}$ \\
\hline O40G2 & $21.42 b$ & $2.52 \mathrm{~b}$ & $3.08 \mathrm{~b}$ & $11.02 \mathrm{~b}$ & $1.23 \mathrm{ab}$ & $5.60 \mathrm{~b}$ & $0.51 \mathrm{ab}$ & $77.60 \mathrm{bB}$ \\
\hline O60 & $20.68 b$ & 2.43 & $3.16 \mathrm{ab}$ & $11.68 \mathrm{~b}$ & $1.30 \mathrm{a}$ & $5.59 \mathrm{~b}$ & $0.48 \mathrm{ab}$ & $83.47 \mathrm{abAB}$ \\
\hline O60G1 & $23.62 \mathrm{ab}$ & $2.74 \mathrm{~b}$ & $3.14 \mathrm{ab}$ & $13.55 \mathrm{~b}$ & $1.18 \mathrm{ab}$ & $5.88 \mathrm{~b}$ & $0.45 \mathrm{ab}$ & $82.06 \mathrm{abAB}$ \\
\hline O60G2 & $23.10 \mathrm{~b}$ & $2.66 \mathrm{~b}$ & $3.57 \mathrm{a}$ & $14.29 \mathrm{~b}$ & $1.34 \mathrm{a}$ & $6.23 \mathrm{~b}$ & $0.44 \mathrm{ab}$ & $89.05 \mathrm{abAB}$ \\
\hline RNAN & $19.59 \mathrm{~b}$ & $2.80 \mathrm{~b}$ & $2.73 \mathrm{~b}$ & $13.44 \mathrm{~b}$ & $0.98 \mathrm{ab}$ & $5.53 \mathrm{~b}$ & $0.41 \mathrm{ab}$ & $96.94 \mathrm{abA}$ \\
\hline Forest & $27.11 \mathrm{a}$ & $3.60 \mathrm{a}$ & $3.89 \mathrm{a}$ & 17.68 a & $1.09 \mathrm{a}$ & $7.48 \mathrm{a}$ & $0.42 \mathrm{a}$ & $92.84 \mathrm{a}$ \\
\hline Haying & $21.76 \mathrm{~b}$ & $3.00 \mathrm{~b}$ & $2.82 \mathrm{~b}$ & $13.15 \mathrm{~b}$ & $0.95 \mathrm{~b}$ & $5.82 \mathrm{~b}$ & $0.45 \mathrm{~b}$ & $87.21 \mathrm{~b}$ \\
\hline \multicolumn{9}{|c|}{$0.10-0.20 \mathrm{~m}$} \\
\hline $\mathrm{O} 40$ & $21.29 \mathrm{abB}$ & $2.85 \mathrm{ab}$ & $3.08 \mathrm{ab}$ & $13.45 \mathrm{ab}$ & $1.08 \mathrm{ab}$ & $5.93 \mathrm{ab}$ & $0.44 \mathrm{ab}$ & $91.17 \mathrm{ab}$ \\
\hline O40G1 & $22.38 \mathrm{abAB}$ & $2.71 \mathrm{~b}$ & $3.15 \mathrm{ab}$ & $12.80 \mathrm{ab}$ & $1.16 \mathrm{ab}$ & $5.86 \mathrm{ab}$ & $0.46 \mathrm{ab}$ & $83.45 \mathrm{ab}$ \\
\hline O40G2 & $23.03 \mathrm{aAB}$ & $2.55 \mathrm{~b}$ & $3.03 \mathrm{ab}$ & $11.90 \mathrm{ab}$ & $1.21 \mathrm{ab}$ & $5.58 \mathrm{~b}$ & $0.47 \mathrm{ab}$ & $76.02 \mathrm{ab}$ \\
\hline O60 & $22.05 \mathrm{abB}$ & $2.47 \mathrm{~b}$ & $3.23 \mathrm{ab}$ & $16.83 \mathrm{a}$ & $1.30 \mathrm{a}$ & $5.69 a b$ & $0.36 \mathrm{ab}$ & $102.64 \mathrm{a}$ \\
\hline O60G1 & $25.55 \mathrm{aA}$ & $2.66 \mathrm{~b}$ & $3.01 \mathrm{ab}$ & $15.76 \mathrm{ab}$ & $1.14 \mathrm{ab}$ & $5.66 \mathrm{~b}$ & $0.37 \mathrm{ab}$ & $83.89 a b$ \\
\hline O60G2 & $22.78 \mathrm{aAB}$ & $2.58 \mathrm{~b}$ & $3.27 \mathrm{a}$ & $14.52 \mathrm{ab}$ & $1.27 \mathrm{a}$ & $5.84 \mathrm{ab}$ & $0.42 \mathrm{ab}$ & $89.49 a b$ \\
\hline RNAN & $21.68 \mathrm{abB}$ & $2.83 a b$ & $2.72 \mathrm{ab}$ & $12.93 \mathrm{ab}$ & $0.97 \mathrm{ab}$ & $5.55 \mathrm{~b}$ & $0.44 \mathrm{ab}$ & $85.34 \mathrm{ab}$ \\
\hline Forest & $23.51 \mathrm{a}$ & $3.30 \mathrm{a}$ & $3.42 \mathrm{a}$ & $13.92 \mathrm{a}$ & $1.04 \mathrm{a}$ & $6.72 \mathrm{a}$ & $0.48 \mathrm{a}$ & $87.84 \mathrm{a}$ \\
\hline Haying & $20.13 b$ & $2.58 \mathrm{~b}$ & $2.47 \mathrm{~b}$ & $11.36 \mathrm{~b}$ & $0.96 \mathrm{~b}$ & $5.05 \mathrm{~b}$ & $0.45 \mathrm{~b}$ & $81.52 \mathrm{~b}$ \\
\hline
\end{tabular}

Note: Presence of the same lowercase letters in the columns does not differ from the reference areas by the Dunnett's test at a 5\% probability level. Presence of the same 
uppercase letters in the columns do not differ from each other for the managements evaluated by the Tukey test, at a $5 \%$ probability level.

The results of TOC in the O60G1 management in depth are related to root concentration by the crops and grazing in winter, corroborating the deposition of residues, and, consequently increasing the carbon content in depth (Piñeiro et al., 2010; Martins et al., 2015). Schiavo et al. (2011) and Dortzbach et al. (2015) also observed differences in TOC levels between the management at different depths and, associated to this, there was a higher root increase by forage plants.

The result of the fraction FA in O40 management is related to the deposition and the action on the mineralization of waste deposited on the surface by the action of soil microorganisms, contributing to the formation of low molecular weight compounds that increase the content of that fraction in soil (Primo et al., 2011).

Considering the result of the HA/FA ratio in the 060 management, we observed an increase in the levels of HA compared to the FA. This shows an evolution of soil organic matter, and can be linked to the soil management or simply to the characteristics of the soil, due to better specific conditions for the increase of the fraction HA (Rosset et al., 2016).

The results observed in $\mathrm{HI}$ in the RNAN management indicate a higher degree of humification and, consequently, a higher composition of the humic substances, exceeding the range of 70 to $90 \%$ found in the literature about the participation of the contents of soil organic carbon (Primo et al., 2011; Rosset et al., 2016; Mendonça \& Matos, 2017). Probably due to the presence of forage turnip that has high nitrogen cycling capacity, and tends to enhance the decomposition of waste.

The managements which presented the same lowercase letter of the reference areas did not differ by Dunnett's test ( $\mathrm{p}<0.05)$, and when these were not present, they differed in a higher or lower amount (Table 2). We observed differences in the managements with reference areas in O60 for the variables FA, in the layer $0.05-0.10 \mathrm{~m}$, and HA/FA in the layer 0.00-0.05 m, that differed in lower and upper, respectively, of reference areas (Table 2). In the other layers and variables, we observed similar results only in the haying in the majority of the management, with the forest and in some cases with both reference areas.

The differences observed in the managements in relation to the forest area are due to the short/limited time of experimentation: three years only. Before implementing the experiment, the area was managed in a conventional system with periodical rotation of soil, deteriorating the carbon content and the low residue deposition on soil (Loss et al., 2014; Martins et al., 2015).

The most relevant changes in management, when compared to the witness areas, were observed in the layer of 0.10-0.20 m, especially in the forest, with the highest concentration of winter forage roots and summer crops, they collaborate to maintain the TOC contents and the fractions HA and HUM by the deposition of waste in depth and less human disturbance (Gazolla et al., 2015). According to Rasse et al. (2005), the soil carbon content that comes from the roots of the plants has a longer permanence time, approximately 2.4 times more 
compared to the aerial parts of the plant, and periodic "pruning" by grazing contributes beneficially to the increase in soil carbon content due to the increase in roots.

All types of management have a predominance of carbon in the fraction HA compared to FA. This indicates a greater humification for all, due to the edaphic conditions for the conversion of labile compounds to more recalcitrant forms of SOM (Cunha et al., 2007). This predominance of $\mathrm{HA}$ is related to the addition of residues with a low $\mathrm{C} / \mathrm{N}$ ratio on the soil surface, contributing to a greater biological activity, increasing the carbon mineralization and the production of soluble phenolic compounds that, through polycondensation, form HA, contributes to the increase of their contents in relation to the fraction of FA (Souza et al., 2016).

The HUM in all the management has significantly lower values in the first layers in relation to the forest area, due to the deterioration of that fraction by the old management adopted, periodic rotation of soil and low addition of residue. But in the layer of $0.10-0.20 \mathrm{~m}$, all the management provided similar results to those in the forest area. We think that, with more productive cycles of additional organic matter, the HUM content in the superficial layers can be recovered.

Also in relation to HUM, the highest carbon content was observed regardless of the depth when compared to HA and FA, indicating greater carbon protection due to its recalcitrance to degradation. This predominance may be indicative of improvements on moisture retention, better soil aggregation and higher cation retention, characteristics of great importance when it comes to sustainable production systems (Gazolla et al., 2015).

According to Grinhut et al. (2007) and Barreto et al. (2008), the predominance of the HUM fraction is related to its insolubility and resistance to biodegradation, favored by the formation of stable clay-humic complexes and the predominant mineralogical composition of the soil, which favors organomineral interactions, and increases the protection of the functional groups of easy decomposition, making them less accessible to microorganisms (Santos et al., 2013).

Gazolla et al. (2015), evaluating pasture, no-tillage system and IAPS areas also observed predominance of the HUM fraction, being such characteristics related, in very clayey soils under tropical climate, the protection and interaction of SOM with the mineral fraction of the soil.

The HA/FA ratio is an indicator of the humus quality and expresses the degree of evolution of SOM humification process. We observed that the management did not differ in comparison with reference areas, and in some cases even higher, not being observed values lower than 1.0, only in the areas of hay, in the last two layers, and in the forest the surface layer. The values higher than 1.0 show a maintenance in the HA content to the detriment of the FA fraction, evidencing better preserved soils and thus contributing to soil sustainability and quality (Gazolla et al., 2015), which can be explained by edaphic conditions, such as soil pH, clay content and climate (Ebeling et al., 2011; Martins et al., 2015).

Gazolla et al. (2015), evaluating pasture, no-tillage system, IAPS and Brazilian savannah 
areas, also observed values of HA/FA ratio in the IAPS areas above 1.0. This result indicates performance on the addition of carbon in more resistant forms and preservation of edaphic conditions by the management adopted.

The values of AE in managements compared with reference areas, in particular the forest plot, are related to the low content of FA and HA fractions in the surface layer. This deterioration is due to the previous management adopted with periodic conventional tillage that decreases the addition of SOM. In depth it is possible to observe better results of the transformation of the deposited residues for the formation and increment of these fractions.

For the AE/HUM ratio it is possible to highlight the low values found $(<1.0)$, indicating predominance of the HUM on the FA and HA, due to the high stability between the SOM and the mineral matrix, reflecting a lower degree of perturbation edaphic, and beneficial changes in such environments by adding waste and to favor the stabilization and mineralization of SOM (Valladares et al., 2011; Martins et al., 2015).

Rosset et al. (2016), evaluating areas with different time of no-tillage system adoption (6, 14 and 22), an area with 12 years of no-tillage system and 4 more years of Brachiaria cultivation (Urochloa ruziziensis) intercropped with corn, pasture in a Oxisol presented results similar to those observed in the AE/HUM ratio.

The values obtained for the $\mathrm{HI}$ in the managements plots, when comparing them to plot areas of reference, corroborate the affirmations of Silva \& Mendonça (2007) and Mendonça \& Matos (2017), that humic substances contribute with about 70 to $90 \%$ of the total organic carbon in soil, and in some cases even higher than as we observed in this study.

\subsection{Oxidizable Fractions, Labile and Non-labile}

We observed differences between the managements, in different layers, for F1 in O60, O60G1 and O60G2, F1/F4 in O60, $(\mathrm{F} 1+\mathrm{F} 2) /(\mathrm{F} 3+\mathrm{F} 4)$ in $\mathrm{O} 60$ and $\mathrm{O} 40 \mathrm{G} 1$ and LC/TOC ind O60, O40G2 and O60G2 at which these presented the higher values compared to the others (Table 3). In the other variables and layers there were no differences between the managements when they are compared to each other.

Table 3. Oxidizable fractions (F1, F2, F3 and F4), ratios between the oxidizable fractions $(\mathrm{F} 1 / \mathrm{F} 4$ and $(\mathrm{F} 1+\mathrm{F} 2) /(\mathrm{F} 3+\mathrm{F} 4))$, non-labile carbon (NLC) and the proportion of labile carbon/total organic carbon (LC/TOC) in different soil managements systems

\begin{tabular}{|c|c|c|c|c|c|c|c|c|}
\hline \multirow{2}{*}{ Areas } & F1 & F2 & F3 & F4 & \multirow{2}{*}{ F1/F4 } & \multirow{2}{*}{$\begin{array}{l}(\mathbf{F} 1+\mathbf{F} 2) / \\
(\mathbf{F 3}+\mathbf{F 4})\end{array}$} & \multirow{2}{*}{$\begin{array}{l}\text { NLC } \\
\mathrm{g} \mathrm{kg}^{-1}\end{array}$} & \multirow{2}{*}{$\frac{\text { LC/TOC }}{\%}$} \\
\hline & \multicolumn{4}{|c|}{-----------------g kg } & & & & \\
\hline \multicolumn{9}{|c|}{$0.00-0.05 \mathrm{~m}$} \\
\hline $\mathrm{O} 40$ & $4.70 \mathrm{bB}$ & $6.34 \mathrm{ab}$ & $7.94 \mathrm{ab}$ & $8.34 \mathrm{ab}$ & $0.63 \mathrm{ab}$ & $0.73 \mathrm{ab}$ & $22.62 \mathrm{ab}$ & $17.28 \mathrm{abB}$ \\
\hline O40G1 & $6.37 \mathrm{abAB}$ & $4.88 \mathrm{~b}$ & $5.97 \mathrm{ab}$ & $7.79 \mathrm{ab}$ & $0.89 \mathrm{ab}$ & $0.83 \mathrm{ab}$ & $18.64 \mathrm{~b}$ & $25.51 \mathrm{abAB}$ \\
\hline O40G2 & $6.90 \mathrm{abAB}$ & $4.82 \mathrm{~b}$ & $5.49 \mathrm{ab}$ & $6.37 \mathrm{ab}$ & $1.28 \mathrm{ab}$ & $1.16 \mathrm{ab}$ & $17.41 \mathrm{~b}$ & $29.04 \mathrm{abA}$ \\
\hline
\end{tabular}




\begin{tabular}{lllllllll} 
O60 & $6.56 \mathrm{abAB}$ & $5.83 \mathrm{~b}$ & $7.89 \mathrm{ab}$ & $5.12 \mathrm{ab}$ & $1.93 \mathrm{ab}$ & $1.00 \mathrm{ab}$ & $18.84 \mathrm{~b}$ & $26.05 \mathrm{abAB}$ \\
O60G1 & $7.65 \mathrm{abA}$ & $3.62 \mathrm{~b}$ & $7.76 \mathrm{ab}$ & $8.18 \mathrm{ab}$ & $0.96 \mathrm{ab}$ & $0.71 \mathrm{ab}$ & $19.56 \mathrm{ab}$ & $28.23 \mathrm{abAB}$ \\
O60G2 & $7.50 \mathrm{abA}$ & $3.38 \mathrm{~b}$ & $7.40 \mathrm{ab}$ & $6.45 \mathrm{ab}$ & $1.18 \mathrm{ab}$ & $0.82 \mathrm{ab}$ & $17.23 \mathrm{~b}$ & $30.44 \mathrm{abA}$ \\
RNAN & $5.76 \mathrm{bAB}$ & $3.54 \mathrm{~b}$ & $6.97 \mathrm{ab}$ & $7.26 \mathrm{ab}$ & $0.82 \mathrm{ab}$ & $0.67 \mathrm{ab}$ & $17.77 \mathrm{~b}$ & $24.49 \mathrm{abAB}$ \\
\hline Forest & $7.81 \mathrm{a}$ & $8.79 \mathrm{a}$ & $7.95 \mathrm{a}$ & $7.18 \mathrm{a}$ & $1.09 \mathrm{a}$ & $1.10 \mathrm{a}$ & $23.92 \mathrm{a}$ & $24.60 \mathrm{a}$ \\
Haying & $6.58 \mathrm{~b}$ & $4.07 \mathrm{~b}$ & $9.34 \mathrm{~b}$ & $5.49 \mathrm{~b}$ & $1.30 \mathrm{~b}$ & $0.74 \mathrm{~b}$ & $18.91 \mathrm{~b}$ & $26.07 \mathrm{~b}$ \\
\hline
\end{tabular}

$0.05-0.10 \mathrm{~m}$

\begin{tabular}{lllllllll} 
O40 & $4.01 \mathrm{abB}$ & $4.66 \mathrm{~b}$ & $7.68 \mathrm{ab}$ & $5.76 \mathrm{ab}$ & $0.76 \mathrm{aAB}$ & $0.66 \mathrm{bAB}$ & $18.10 \mathrm{ab}$ & $17.74 \mathrm{abB}$ \\
O40G1 & $6.25 \mathrm{abAB}$ & $4.10 \mathrm{~b}$ & $4.32 \mathrm{a}$ & $6.91 \mathrm{ab}$ & $0.97 \mathrm{abAB}$ & $0.95 \mathrm{abAB}$ & $15.32 \mathrm{~b}$ & $29.52 \mathrm{abAB}$ \\
O40G2 & $4.89 \mathrm{abAB}$ & $4.53 \mathrm{~b}$ & $5.68 \mathrm{a}$ & $6.32 \mathrm{ab}$ & $0.78 \mathrm{aAB}$ & $0.80 \mathrm{bAB}$ & $16.53 \mathrm{~b}$ & $22.90 \mathrm{abAB}$ \\
O60 & $6.80 \mathrm{abA}$ & $3.86 \mathrm{~b}$ & $5.14 \mathrm{a}$ & $5.96 \mathrm{ab}$ & $1.36 \mathrm{abA}$ & $0.99 \mathrm{aA}$ & $13.88 \mathrm{~b}$ & $32.84 \mathrm{bA}$ \\
O60G1 & $5.60 \mathrm{abAB}$ & $4.48 \mathrm{~b}$ & $5.40 \mathrm{a}$ & $8.13 \mathrm{a}$ & $0.70 \mathrm{aAB}$ & $0.75 \mathrm{bAB}$ & $18.02 \mathrm{ab}$ & $23.76 \mathrm{abAB}$ \\
O60G2 & $6.09 \mathrm{abAB}$ & $3.33 \mathrm{~b}$ & $5.73 \mathrm{a}$ & $7.95 \mathrm{a}$ & $0.85 \mathrm{aAB}$ & $0.69 \mathrm{bAB}$ & $17.01 \mathrm{~b}$ & $26.38 \mathrm{abAB}$ \\
RNAN & $3.65 \mathrm{abB}$ & $3.81 \mathrm{~b}$ & $4.71 \mathrm{a}$ & $7.42 \mathrm{a}$ & $0.49 \mathrm{aB}$ & $0.62 \mathrm{bB}$ & $15.94 \mathrm{~b}$ & $18.65 \mathrm{abB}$ \\
\hline Forest & $5.78 \mathrm{a}$ & $8.78 \mathrm{a}$ & $5.95 \mathrm{a}$ & $6.60 \mathrm{a}$ & $0.92 \mathrm{a}$ & $1.17 \mathrm{a}$ & $21.33 \mathrm{a}$ & $21.34 \mathrm{a}$ \\
Haying & $5.80 \mathrm{~b}$ & $2.75 \mathrm{~b}$ & $9.21 \mathrm{~b}$ & $3.83 \mathrm{~b}$ & $1.52 \mathrm{~b}$ & $0.66 \mathrm{~b}$ & $15.96 \mathrm{~b}$ & $26.58 \mathrm{~b}$ \\
\hline & & & & $0.10-0.20 \mathrm{~m}$ & & & \\
O40 & $4.97 \mathrm{ab}$ & $3.75 \mathrm{~b}$ & $6.84 \mathrm{ab}$ & $5.74 \mathrm{ab}$ & $0.86 \mathrm{ab}$ & $0.72 \mathrm{bAB}$ & $16.32 \mathrm{ab}$ & $23.44 \mathrm{ab}$ \\
O40G1 & $6.20 \mathrm{ab}$ & $5.17 \mathrm{a}$ & $4.18 \mathrm{a}$ & $6.83 \mathrm{ab}$ & $0.96 \mathrm{a}$ & $1.06 \mathrm{aA}$ & $16.18 \mathrm{ab}$ & $27.82 \mathrm{ab}$ \\
O40G2 & $4.91 \mathrm{ab}$ & $5.06 \mathrm{a}$ & $6.21 \mathrm{ab}$ & $6.85 \mathrm{ab}$ & 0.73 & $0.77 \mathrm{bAB}$ & $18.12 \mathrm{a}$ & $21.46 \mathrm{a}$ \\
O60 & $5.37 \mathrm{ab}$ & $4.83 \mathrm{a}$ & $4.72 \mathrm{a}$ & $7.13 \mathrm{~b}$ & 0.84 & $0.87 \mathrm{abAB}$ & $16.69 \mathrm{ab}$ & $24.30 \mathrm{ab}$ \\
O60G1 & $6.39 \mathrm{ab}$ & $3.84 \mathrm{~b}$ & $7.05 \mathrm{ab}$ & 8.26 & 0.78 & $0.67 \mathrm{bAB}$ & $19.15 \mathrm{a}$ & $25.14 \mathrm{ab}$ \\
O60G2 & $4.92 \mathrm{ab}$ & $4.97 \mathrm{a}$ & $5.15 \mathrm{a}$ & 7.74 & 0.64 & $0.79 \mathrm{bAB}$ & $17.85 \mathrm{a}$ & $21.68 \mathrm{a}$ \\
RNAN & $5.06 \mathrm{ab}$ & $2.97 \mathrm{~b}$ & $7.19 \mathrm{ab}$ & $6.46 \mathrm{ab}$ & 0.83 & $0.61 \mathrm{bB}$ & $16.62 \mathrm{ab}$ & $23.38 \mathrm{ab}$ \\
\hline Forest & $5.29 \mathrm{a}$ & $7.25 \mathrm{a}$ & $6.86 \mathrm{a}$ & $4.12 \mathrm{a}$ & $1.37 \mathrm{a}$ & $1.16 \mathrm{a}$ & $18.23 \mathrm{a}$ & $22.51 \mathrm{a}$ \\
\hline & $6.03 \mathrm{~b}$ & $1.64 \mathrm{~b}$ & $8.19 \mathrm{~b}$ & $4.28 \mathrm{~b}$ & $1.45 \mathrm{~b}$ & $0.62 \mathrm{~b}$ & $14.11 \mathrm{~b}$ & $29.94 \mathrm{~b}$ \\
\hline
\end{tabular}

Note: Presence of the same lowercase letters in the columns does not differ from the reference areas by the Dunnett's test at a 5\% probability level. Presence of the same uppercase letters in the columns do not differ from each other for the managements evaluated by the Tukey test, at a $5 \%$ probability level.

In relation to the values of $\mathrm{F} 1$ and $\mathrm{LC} / \mathrm{TOC}$, the highest results observed in the above 
mentioned management can be related to rapid decomposition and mineralization of the residues by the microorganism of the soil, which increases labile carbon content easily, consequently improving short-term nutrient cycling, in addition to the outstanding contribution to the formation and stabilization of transient aggregates (Santos et al., 2013).

For the $\mathrm{F} 1 / \mathrm{F} 4$ and $(\mathrm{F} 1+\mathrm{F} 2) /(\mathrm{F} 3+\mathrm{F} 4)$ ratios, the high values observed are related to the depth of root deposition, which, due to their longer residence time, tend to corroborate the increase of carbon in the more recalcitrant fractions of soil (Rasse et al., 2005) Moreover, the closer to 1.0 , the better it is the distribution of the carbon contents between the labile and recalcitrant fractions in the soil (Loss et al., 2014).

Comparing the managements with parcel areas of reference, it is observed in the $0.10-0.20 \mathrm{~m}$ layer, for F4 variable in managements O60G1 and O60G2 and F1/F4 in O40G2, O60, O60G1, O60G2 and RNAN results statistically superior and inferior with respect to reference areas. In the other layers and variables, similar results were observed in most of the managements: in some cases only the haying, in others the forest and, in some other cases both reference areas (Table 3).

For F1 it is possible to observe that even with little time of implantation of the evaluated manures they were able to provide similar values to the control areas, especially the forest, by the input of residues from different origins, possibly due to accelerated decomposition and mineralization of these residues due to low $\mathrm{C} / \mathrm{N}$ ratio $(<30: 1)$ (Batista et al., 2014).

Guareschi et al. (2013), evaluating areas of native forest, pasture planted with Brachiaria decumbens, no-tillage system with 3 years, no-tillage system with 15 years and no-tillage system with 20 years of implantation in the central west region of Brazil, obtained results similar to those observed in the F1 fraction.

For F2 it is possible to observe in the evaluated layers for most of the managements, that they were statistically inferior to the forest, except in the layer 0,10-0,20 m for O40, O40G1, O40G2, O60 and O60G2, being able to reflect the little time of the conversion of the fraction easily labile to the labile or by the very nature of the deposited material because it is more resistant to degradation. Consequently, it takes more time to liberate carbon into the soil in labile forms.

Rosset et al. (2016), evaluating the soil quality from the chemical and oxidizable fractions of organic matter in areas with different times of adoption of the no-tillage system $(6,14$ and 22 years), an area with 12 years of no-tillage system and 4 years more of cultivation of forage (Urochloa ruziziensis) intercropped with corn and pasture and native forest area, also obtained similar results for the values of fraction F1 and F2.

The highest concentration of carbon, regardless of the evaluated layer, is observed in fractions F3 and F4, and only in the forest it is possible to observe impartiality between the fractions. These results may indicate a higher performance for the formation of substances with higher molecular weight and chemical stability, resulting from the decomposition and humification of the deposited residues to increment SOM (Stevenson, 1994), mainly due to the higher $\mathrm{C} / \mathrm{N}$ ratio of the remains of crops and deposited animal waste deposited by the 
management.

According to Chan et al. (2001) and Guareschi et al. (2013), F3 and F4 fractions are more resistant in the soil and present a longer residence time compared to F1 and F2 fractions. As noted in the study, it is corroborated a lower variation in moisture content and temperature, therefore creating an environment more favorable for the maintenance of organic matter levels and the same stability.

For the F1/F4 and $(\mathrm{F} 1+\mathrm{F} 2) /(\mathrm{F} 3+\mathrm{F} 4)$ relationships, the values obtained in the great majority of the managements, regardless of the evaluated layer, were lower than 1.0, demonstrating the predominance of difficult degradation carbon, due to its higher resistance to oxidation by the action of microorganisms, as well as the fact that the very clayey texture provides greater protection against degradation by microorganisms (Guareschi et al., 2013).

According to Rosset et al. (2016) when smaller values were obtained within the relations $\mathrm{F} 1 / \mathrm{F} 4$ and $(\mathrm{F} 1+\mathrm{F} 2) /(\mathrm{F} 3+\mathrm{F} 4)$, it may mean a lower input of plant material of greater lability, which may not be related with the quality of residues deposited on the ground, but with the rapid transformation of the labile carbon into recalcitrant form in order to recover the contents within the fractions F3 and F4 that were affected by the old management adopted.

We observed the predominance of the NLC fraction in relation to the $\mathrm{LC}(\mathrm{F} 1)$, indicating formation of more recalcitrant carbon reserves in the soil, since this fraction has a slower cycle and acts both as a nutrient reserve and in the chemical stability of microaggregates in the soil (Guareschi et al., 2013), confirming what we saw in the F1/F4 relationships and $(\mathrm{F} 1+\mathrm{F} 2) /(\mathrm{F} 3+\mathrm{F} 4)$ that is beginning the recovery of the most resistant soil carbon by the management.

For the LC/TOC ratio the values obtained indicate lower residue permanence in the evaluated manures, and they explain the results, probably due to the grazing intensity or the accelerated decomposition by the microorganisms, due to climatic factors and $\mathrm{C} / \mathrm{N}$ ratio of the residues, contributing to the conversion of LC into more recalcitrant fractions, in this case the NLC.

\subsection{Carbon Management Index}

We observed differences between the managements, in the 0.00-0.05 and 0.05-0.10 m layers, in all indexes and in O60G2, O60G1 and O60 the highest values were found among the others (Table 4). It is possible to observe in the surface layers the improvements within the indices are linked to the results observed within the oxidizable fractions.

Table 4. Carbon compartment index (CCI), lability (L), lability index (IL) and carbon management index (CMI) in different management systems

\begin{tabular}{|c|c|c|c|c|}
\hline Areas & CCI & $\mathbf{L}$ & IL & CMI \\
\hline & \multicolumn{4}{|c|}{$0.00-0.05 \mathrm{~m}$} \\
\hline $\mathrm{O} 40$ & $0.60 \mathrm{~B}$ & $0.21 \mathrm{abB}$ & $0.64 \mathrm{abB}$ & $39.32 \mathrm{abB}$ \\
\hline O40G1 & $0.82 \mathrm{abAB}$ & $0.35 \mathrm{abAB}$ & $1.06 \mathrm{abAB}$ & $88.53 \mathrm{abAB}$ \\
\hline
\end{tabular}




\begin{tabular}{|c|c|c|c|c|}
\hline O40G2 & $0.88 \mathrm{abAB}$ & $0.42 \mathrm{abAB}$ & $1.29 \mathrm{abAB}$ & $117.10 \mathrm{abAB}$ \\
\hline O60 & $0.84 \mathrm{abAB}$ & $0.36 \mathrm{abAB}$ & $1.11 \mathrm{abAB}$ & $100.92 \mathrm{abAB}$ \\
\hline O60G1 & $0.98 \mathrm{abA}$ & $0.40 \mathrm{abAB}$ & $1.21 \mathrm{abAB}$ & $119.32 \mathrm{abAB}$ \\
\hline O60G2 & $0.96 \mathrm{abA}$ & $0.44 \mathrm{abA}$ & $1.34 \mathrm{abA}$ & $129.82 \mathrm{abA}$ \\
\hline RNAN & $0.74 \mathrm{bAB}$ & $0.32 \mathrm{abAB}$ & $0.99 \mathrm{abAB}$ & $73.43 \mathrm{abAB}$ \\
\hline Forest & $1.00 \mathrm{a}$ & $0.33 \mathrm{a}$ & $1.00 \mathrm{a}$ & $100.00 \mathrm{a}$ \\
\hline Haying & $0.84 \mathrm{~b}$ & $0.35 \mathrm{~b}$ & $1.08 \mathrm{~b}$ & $91.47 \mathrm{~b}$ \\
\hline \multicolumn{5}{|c|}{$0.05-0.10 \mathrm{~m}$} \\
\hline $\mathrm{O} 40$ & $0.69 \mathrm{abB}$ & $0.22 \mathrm{abB}$ & $0.80 \mathrm{abB}$ & $60.88 \mathrm{abB}$ \\
\hline O40G1 & $1.08 \mathrm{abAB}$ & $0.43 \mathrm{abAB}$ & $1.56 \mathrm{abAB}$ & $172.56 \mathrm{abAB}$ \\
\hline O40G2 & $0.85 \mathrm{abAB}$ & $0.30 \mathrm{abAB}$ & $1.09 \mathrm{abAB}$ & $93.87 \mathrm{abAB}$ \\
\hline O60 & $1.18 \mathrm{abA}$ & $0.50 \mathrm{bA}$ & $1.85 \mathrm{bA}$ & $233.28 \mathrm{bA}$ \\
\hline O60G1 & $0.97 \mathrm{abAB}$ & $0.31 \mathrm{abAB}$ & $1.15 \mathrm{abAB}$ & $112.97 \mathrm{abAB}$ \\
\hline O60G2 & $1.05 \mathrm{abAB}$ & $0.36 \mathrm{abAB}$ & $1.33 \mathrm{abAB}$ & $146.44 \mathrm{abAB}$ \\
\hline RNAN & $0.63 \mathrm{~B}$ & $0.23 \mathrm{abB}$ & $0.85 \mathrm{abB}$ & $55.01 \mathrm{abB}$ \\
\hline Forest & $1.00 \mathrm{a}$ & $0.27 \mathrm{a}$ & $1.00 \mathrm{a}$ & $100.00 \mathrm{a}$ \\
\hline Haying & $1.00 \mathrm{~b}$ & $0.36 \mathrm{~b}$ & $1.33 \mathrm{~b}$ & $134.11 \mathrm{~b}$ \\
\hline \multicolumn{5}{|c|}{$0.10-0.20 \mathrm{~m}$} \\
\hline $\mathrm{O} 40$ & $0.94 \mathrm{ab}$ & $0.31 \mathrm{a}$ & $1.07 \mathrm{ab}$ & $106.67 \mathrm{ab}$ \\
\hline O40G1 & $1.17 \mathrm{ab}$ & $0.39 \mathrm{ab}$ & $1.33 \mathrm{ab}$ & $156.36 \mathrm{ab}$ \\
\hline O40G2 & $0.93 \mathrm{ab}$ & $0.29 \mathrm{a}$ & $0.95 \mathrm{a}$ & $91.52 \mathrm{a}$ \\
\hline O60 & $1.02 \mathrm{ab}$ & $0.32 \mathrm{ab}$ & $1.10 \mathrm{ab}$ & $112.37 \mathrm{ab}$ \\
\hline O60G1 & $1.21 \mathrm{ab}$ & $0.34 \mathrm{ab}$ & $1.16 \mathrm{ab}$ & $141.18 \mathrm{ab}$ \\
\hline O60G2 & $0.93 \mathrm{ab}$ & $0.28 \mathrm{a}$ & $0.96 \mathrm{a}$ & $93.88 \mathrm{a}$ \\
\hline RNAN & $0.96 \mathrm{ab}$ & $0.31 \mathrm{ab}$ & $1.05 \mathrm{a}$ & $100.18 \mathrm{a}$ \\
\hline Forest & $1.00 \mathrm{a}$ & $0.29 \mathrm{a}$ & $1.00 \mathrm{a}$ & $100.00 \mathrm{a}$ \\
\hline Haying & $1.14 \mathrm{~b}$ & $0.43 \mathrm{~b}$ & $1.46 \mathrm{~b}$ & $167.26 \mathrm{~b}$ \\
\hline
\end{tabular}

Note: Presence of the same lowercase letters in the columns does not differ from the reference areas by the Dunnett's test at a 5\% probability level. Presence of the same uppercase letters in the columns do not differ from each other for the managements evaluated by the Tukey test, at a $5 \%$ probability level. 
The values obtained by the F1 fraction, which is the basis of calculation for these indices and differences, were observed in the first layers of the soil, and may have relation to the decomposition of animal and vegetable waste in the superficial and deep layers corroborated for the increment of carbon in the labile and non-labile form providing improvement on the abovementioned indices between the different managements.

Comparing the managements with the reference areas observed in O40, from the layer 0.00-0.05 and 0.05-0.10 m, results were lower than the control areas for CCI. In the other areas and layers, no differences were observed in most of the treatments with the reference areas (Table 4).

In CCI the values obtained in the managements were close to 1.0 indicating proximity of the TOC contents in relation to the reference. This shows the potential to increase the carbon content in the soil of the evaluated managements, even with the short time of adoption, provided by the deposition of residues of different natures and less anthropic action on edaphic disruption, and thus, less degradation and higher maintenance of soil carbon (Rangel et al., 2008).

In the results obtained for L, we observe that the highest proportion of NLC in relation to LC, provided values that were less than 1.0, which indicates a higher conversion of carbon in most recalcitrant fractions. For IL, values above 1.0 were observed in all managements indicating lability of the managements evaluated in relation to reference areas, and an increase in soil carbon bioavailability (Rangel et al., 2008).

In relation with the values obtained for the CMI in all the layers and managements to maintain or increase of the soil carbon content, the results were similar to those obtained by Schiavo et al. (2011), who evaluated areas with a different time of adoption in a Oxisol of clay texture, found values near to reference area, 101.77 and 111.61 for the layers of 0.00-0.05 and 0.10-0.20 m, respectively, for an area with integration and pasture formed by species of the genus Urochloa.

Silva et al. (2011) evaluating the total carbon and nitrogen stocks of the labile and recalcitrant fractions of SOM and CMI, in the IAPS, after four and eight years of implantation, comparing with several management systems such as pasture, no-tillage system and forest areas, it got to the IAPS with eight years similar CMI values that in the native forest area.

While Isernhagen et al. (2017), evaluating different management in the Cerrado and Amazonia Transition region, on a Oxisol of clayey texture obtained lower results than those observed in the present study for areas with crop-livestock-forest integration with three years of implantation, obtaining CMI values of 53, 57 and 62 for the layers of $0.00-0.05,0.05-0.10$ and $0.10-0.20 \mathrm{~m}$, respectively.

It is possible to emphasize that the evaluated management contributed to the maintenance of the soil carbon contents. However, it is worth noting that the efficiency of a system in the recovery of soil quality depends, besides the characteristics of this management, on the degradation process of the soil, such as overpasses, soil exploitation and low production of residues (Reis et al., 2016; Isernhagen et al., 2017). 


\section{Conclusions}

The different configurations of IAPS, in particular O60G1 and O60G2, provided changes in the total organic carbon, fractions of humic substances, oxidizables fractions and carbon management index when compared to the other managements and these do not greatly differ from reference areas. Demonstrating that they are alternatives to be adopted by the producers who seek to replace hay production areas by IAPS in a sustainable way, in order to preserve the quality of the soil.

\section{Acknowledgements}

This study was financed in part by the Coordenação de Aperfeiçoamento de Pessoal de Nível Superior - Brasil (CAPES) - Finance Code 001. We want to give thanks to the Coordination for the Improvement of Higher Education Personnel (CAPES) by the scholarship and resources for conducting the research and the National Council for Scientific and to Technological Development $(\mathrm{CNPq})$ for the productivity scholarship granted to the Dr. Paulo Sérgio Rabello de Oliveira.

\section{References}

Alvares, C. A., Stape, J. L., Sentelhas, P. C., Moraes Gonçalves, J. L., \& Sparovek, G. (2014). Köppen's climate classification map for Brazil. Meteorologische Zeitschrift, 22(6), 711-728. https://doi.org/10.1127/0941-2948/2013/0507

Barreto, A. C., Santos Freire, M. B. G., Nacif, P. G. S., Araujo, Q. R., Freire, F. J., \& Inácio, E. S. B. (2008). Chemical and physical fractions of soil organic carbon in a forest soil currently under different uses. Revista Brasileira de Ciências do Solo, 32(4), 1471-1478. https://doi.org/10.1590/S0100-06832008000400011

Batista, I., Correia, M. E. F., Pereira, M. G., Bieluczyk, W., Schiavo, J. A., Rouws, J. R. C. (2014). Oxidizable fractions of total organic carbon and soil macrofauna in a crop-livestock integration system. Revista Brasileira de Ciências do Solo, 38(3), 797-809. https://doi.org/10.1590/S0100-06832014000300011

Blair, G. J., Lefroy, D. B., \& Lisle, L. (1995). Soil carbon fractions based on their degree of oxidation, and the development of a carbon management index for agricultural systems. Australian Journal of Agricultural Research, 46(7), 1459-1460. https://doi.org/10.1071/AR9951459

Canellas, L. P., \& Santos, G. A. (2005). Humosfera: tratado preliminar sobre a química das substâncias húmicas. (1rd ed.). Campos dos Goytacazes: UENF, Brazil. p. 309.

Chan, K. Y., Bowman, A., \& Oates, A. (2001). Oxidizible organic carbon fractions and soil quality changes in an Paleustalf under different pasture leys. Soil Science, 166(1), 61-67. https://doi.org/10.1097/00010694-200101000-00009

Cordeiro, L. A. M., Vilela, L., Marchão, R. L., Kluthcouski, J., \& Martha Júnior, G. B. (2015). Integrated crop-livestock and integrated crop-livestock-forest systems: strategies for sustainable intensification of soil use. Cadernos de Ciência \& Tecnologia, 32(1-2), 15-53. 
http://dx.doi.org/10.35977/0104-1096.cct2015.v32.23294

Cruz, C. D. (2013). Genes: A software package for analysis in experimental statistics and quantitative genetics. Acta Scientiarum Agronomy, 35(3), 271-276. https://doi.org/10.4025/actasciagron.v35i3.21251

Cunha, T. J. F., Madari, B. E., Benites, V. M., Canellas, L. P., Novotny, E. H., Moutta, R. O., ... Santos, G. A. (2007). Chemical fractionation of organic matter and humic acid characteristic in anthropogenic dark earth soils of brazilian amazonic region. Acta Amazônic, 37(1), 91-98. https://doi.org/10.1590/S0044-59672007000100010

Dortzbach, D., Pereira, M. G., Blainski, E., \& Gonzalez, A. P. (2015). Carbon stock and natural abundance of $13 \mathrm{C}$ as a function of conversion of forest and grassland areas in southern Brazil. Revista Brasileira de Solo, 39(6), 1643-1660. https://doi.org/10.1590/01000683rbcs20140531

Ebeling, A. G., Anjos, L. H. C., Pereira, M. G., Pinheiro, E. F. M., \& Valladares, G. S. (2011). Humic substances and relationship to soil atributes. Bragantia, 70(1), 157-165. https://doi.org/10.1590/S0006-87052011000100022

Ferreira, D. F., Filho, A. C., \& Lucio, A. D. (2012). Procedimentos estatísticos em planejamentos experimentais com restrição na casualização. Boletim Informativo Sociedade Brasileira de Ciência do Solo, 37(3), 16-19.

Gazolla, P. R., Guareschi, R. C., Perin, A., Pereira, M. G., \& Rossi, C. Q. (2015). Fractions of soil organic matter under pasture, tillage system and crop-livestock integration. Semina: Ciências Agrárias, 36(2), 693-704. https://doi.org/10.5433/1679-0359.2015v36n2p693

Grinhut, T., Hadar, Y., \& Chen, Y. (2007). Degradation and transformation of humic substances by saprotrophic fungi: processes and mechanisms. Fungal Biology Reviews, 21(4), 179-189. https://doi.org/10.1016/j.fbr.2007.09.003

Guareschi, R. F., Pereira, M. G., \& Perin, A. (2013). Oxidizable carbon fractions in Red Latosol under different management systems. Revista Ciência Agronômica, 44(2), 242-250. https://doi.org/10.1590/S1806-66902013000200005

Isernhagen, E. C. C., Rodrigues, R. A. R., Diel, D., Matos, D. S., \& Conceição, M. C. G. (2017). Labile and total carbon pools in soil under integrated crop-livestock-forest system in the Cerrado/Amazonia Ecotone. Nativa, 5(n.esp.), 515-521. https://doi.org/10.5935/2318-7670.v05nespa09

Loss, A., Ribeiro, E. C., Pereira, M. G., \& Costa, E. M. (2014). Physical and chemical attributes in systems of the consortium and succession of crops, pasture and silvopastoral in Santa Teresa, Espírito Santo State, Brazil. Bioscience Journal, 30(5), 1347-1357.

Martins, C. M., Costa, L. M., Schaefer, C. E. G. R., Soares, E. M. B., \& Santos, S. R. (2015). Fraction of organic matter in soil under deciduous formations in the north of minas. Revista Caatinga, 28(4), 10-20. https://doi.org/10.1590/1983-21252015v28n402rc 
Mendonça, E. S., \& Matos, E. S. (2017). Matéria orgânica do solo: métodos de análises. (2rd ed). Viçosa: UFV/Gefert, Brazil. p. 221.

Piñeiro, G., Paruelo, J. M., Oesterheld, M., \& Jobbágy, E. G. (2010). Pathways of grazing effects on soil organic carbon and nitrogen. Rangeland Ecology \& Management, 63(1), 109-119. https://doi.org/10.2111/08-255.1

Primo, D. C., Menezes, R. C., \& Silva, T. O. (2011). Substâncias húmicas da matéria orgânica do solo: uma revisão de técnicas analíticas e estudos no nordeste brasileiro. Scientia Plena, 7(5), 1-13.

Rangel, O. J. P., Silva, C. A., Guimarães, P. T. G., \& Guilherme, L. R. G. (2008). Oxidizible organic carbon fractions in a latosol cultivated with coffee at different planting spacings. $\begin{array}{llll}\text { Ciencia } & e & \text { agrotecnologia, } & 32(2),\end{array}$ https://doi.org/10.1590/S1413-70542008000200013

Rasse, D. P., Rumpel, C., \& Dignac, M. F. (2005). Is soil carbon mostly root carbon? mechanisms for a specific stabilization. Plant Soil, 269(1-2), 341-356. https://doi.org/10.1007/s11104-004-0907-y

Reis, D. A., Lima, C. L. R., \& Bamberg, A. L. (2016). Physical quality and organic matter fractions of an Alfisol under no-tillage. Pesquisa Agropecuária Brasileira, 51(9), 1623-1632. https://doi.org/10.1590/s0100-204x2016000900062

Rosset, J. S., Lana, M. C., Pereira, M. G., Schiavo, J. A., Rampim, L., \& Sarto, M. V. M. (2016). Chemical and oxidizable fractions of soil organic matter under different management systems in an Oxisol. Pesquisa Agropecuária Brasileira, 51(9), 1529-1538. https://doi.org/10.1590/s0100-204x2016000900052

Rossi, C. Q., Pereira, M. G., Giácomo, S. G., Betta, M., \& Polidoro, J. C. (2012). Organic fractions and soil organic carbono management index in an Oxisol under soybean cultivation in the cerrado region of Goiás, Brazil. Revista Brasileira de Ciências Agrarias, 7(2), 233-241. https://doi.org/10.5039/agraria.v7i2a1387

Santos, D. C., Farias, M. O., Lima, C. L. R., Kunde, R. J., Pillon, C. N., \& Flores, C. A. (2013). Physical and chemical fractionation of organic matter of an Alfisol under different use systems. Ciência Rural, $\quad 43(5), \quad 838-844$. https://doi.org/10.1590/S0103-84782013005000037

Schiavo, J. A., Rosset, J. R., Pereira, M. G., \& Salton, J. C. (2011). Carbon management index and chemical attributes of an Oxisol under different management systems. Pesquisa Agropecuária Brasileira, $\quad 46(10), \quad 1332-1338$. https://doi.org/10.1590/S0100-204X2011001000029

Silva, E. F., Lourente, E. P. R., Marchetti, M. E., Mercante, F. M., Ferreira, A. K. T., \& Fuji, G. C. (2011). Labile and recalcitrant fractions of soil organic matter under integrated crop-livestock system. Pesquisa Agropecuária Brasileira, 46(10), 1321-1331. https://doi.org/10.1590/S0100-204X2011001000028 
Silva, I. R., \& Mendonça, E. S. (2007). Matéria orgânica do solo. In: Novais Rf, Alvarez Vvh, Barros Nf, Fontes Rlf, Cantarutti Rb, Neves Jcl (EDS). Fertilidade do Solo, pp. 275-374. Viçosa: Sociedade Brasileira de Ciência do Solo, Brazil.

Souza, G. P., Figueiredo, C. C., \& Sousa, D. M. G. (2016). Soil organic matter as affected by management systems, phosphate fertilization, and cover crops. Pesquisa Agropecuária Brasileira, 51(9), 1668-1676. https://doi.org/10.1590/s0100-204x2016000900067

Stevenson, F. J. (1994). Humus chemistry: genesis, composition, reactions. (2rd ed). New York: J. Wiley \& Sons, United States of America. p. 512.

Valladares, G. S., Batistella, M., \& Pereira, M. G. (2011). Changes promoted by management in Oxisol, Rondônia, Brazilian Amazon. Bragantia, 70(3), 631-637. https://doi.org/10.1590/S0006-87052011000300019

\section{Copyright Disclaimer}

Copyright for this article is retained by the author(s), with first publication rights granted to the journal.

This is an open-access article distributed under the terms and conditions of the Creative Commons Attribution license (http://creativecommons.org/licenses/by/4.0/). 